\title{
Association of triglycerides with HOMA-IR in normal glucose tolerant first degree relatives of patients with diabetes
}

\author{
M Aslam, AA Siddiqui, S Goyal, BK Mishra, SV Madhu
}

Department of Endocrinology, Centre for Diabetes Endocrinology \& Metabolism, University College of Medical Sciences (University of Delhi) \& GTB Hospital, Delhi, India

\section{BACKGROUND}

Association of hypertriglyceridemia with type 2 diabetes is well known. However, their causeeffect relationship is not established. Most of the studies show that hypertriglyceridemia is the result of type 2 diabetes whereas some studies including from own group suggest that higher triglyceride levels may be the cause of type 2 diabetes. Present study was therefore undertaken to study the association of serum triglycerides with HOMA-IR in healthy subjects.

\section{OBJECTIVE}

To study the association of serum triglyceride levels with HOMA-IR in normal glucose tolerance (NGT) first degree relatives of patients with diabetes.

\section{METHODOLOGY}

Six hundred seventeen $(\mathrm{n}=617)$ age and sex matched subjects with normal glucose tolerance (NGT) were recruited in two groups.

Group 1: NGT subjects who had a first degree relative with diabetes $(n=314)$

Group 2: NGT subjects without family history of diabetes $(n=303)$.

Normal glucose tolerance (NGT) was defined on the basis of oral glucose tolerance test.

Body mass index and waist circumference were measured in all the study subjects.

Biochemical parameters viz HbAlc, fasting serum insulin and lipid profile were measured in all the study subjects.

Statistical analysis: Unpaired t-test was applied to compare anthropometric and biochemical parameters between the two groups. Pearson's coefficient of correlation was used to study the association between various parameters.
Subjects in both the groups have been matched for age and sex. Male to female ratio was 1:1.1 in both the groups. Body mass index, waist circumference, fasting and 2 hour postprandial plasma glucose, $\mathrm{HbAlc}$, fasting serum insulin and HOMA-IR were found to be significantly higher in group 1 compared to group 2 (Table 1 and 2). No significant difference was observed in any of the lipid parameters between group 1 and group 2 (Table 3).

Table 2: Glycemic and insulin parameters of study subjects

\begin{tabular}{|c|c|c|c|}
\hline Parameter & $\begin{array}{c}\text { Group 1 } \\
\text { Mean } \pm \text { SD }\end{array}$ & $\begin{array}{c}\text { Group 2 } \\
\text { Mean } \pm \text { SD }\end{array}$ & $\begin{array}{c}\text { Statistical } \\
\text { Significance }\end{array}$ \\
\hline $\begin{array}{c}\text { Fasting plasma } \\
\text { glucose (mg/dl) }\end{array}$ & $88.02 \pm 11.91$ & $84.44 \pm 9.03$ & $\mathrm{P}=<0.001$ \\
\hline $\begin{array}{c}\text { 2 hr postprandial } \\
\text { plasma glucose (mg/ } \\
\text { dl) }\end{array}$ & $108.04 \pm 22.52$ & $102.69 \pm 18.16$ & $\mathrm{P}=0.001$ \\
\hline HbAlc (\%) & $5.63 \pm 0.56$ & $5.48 \pm 0.48$ & $\mathrm{P}=0.001$ \\
\hline $\begin{array}{c}\text { Fasting serum insulin } \\
\text { (IU/L) }\end{array}$ & $7.72 \pm 5.86$ & $5.75 \pm 4.36$ & $\mathrm{P}=<0.001$ \\
\hline HOMA-IR & $1.69 \pm 1.44$ & $1.21 \pm 1.05$ & $\mathrm{P}=<0.001$ \\
\hline
\end{tabular}

Table 3: Lipid profile of study subjects

\begin{tabular}{|c|c|c|c|}
\hline Parameter & $\begin{array}{c}\text { Group 1 } \\
\text { Mean } \pm \text { SD }\end{array}$ & $\begin{array}{c}\text { Group 2 } \\
\text { Mean } \pm \text { SD }\end{array}$ & $\begin{array}{c}\text { Statistical } \\
\text { Significance }\end{array}$ \\
\hline $\begin{array}{c}\text { Triglyceride }(\mathrm{mg}) \\
\text { dl) }\end{array}$ & $133.96 \pm$ & $138.17 \pm$ & $\mathrm{P}=0.44$ \\
\hline $\begin{array}{c}\text { Total Cholesterol } \\
(\mathrm{mg} / \mathrm{dl})\end{array}$ & $179.68 \pm$ & $177.69 \pm$ & $\mathrm{P}=0.57$ \\
\hline HDLc (mg/dl) & $43.62 \pm$ & $43.37 \pm$ & $\mathrm{P}=0.73$ \\
\hline LDLc (mg/dl) & $108.86 \pm$ & $106.29 \pm$ & $\mathrm{P}=0.42$ \\
\hline VLDLc (mg/dl) & $27.19 \pm$ & $28.03 \pm$ & $\mathrm{P}=0.44$ \\
\hline
\end{tabular}

Correlations of triglyceride with measures of obesity and insulin sensitivity
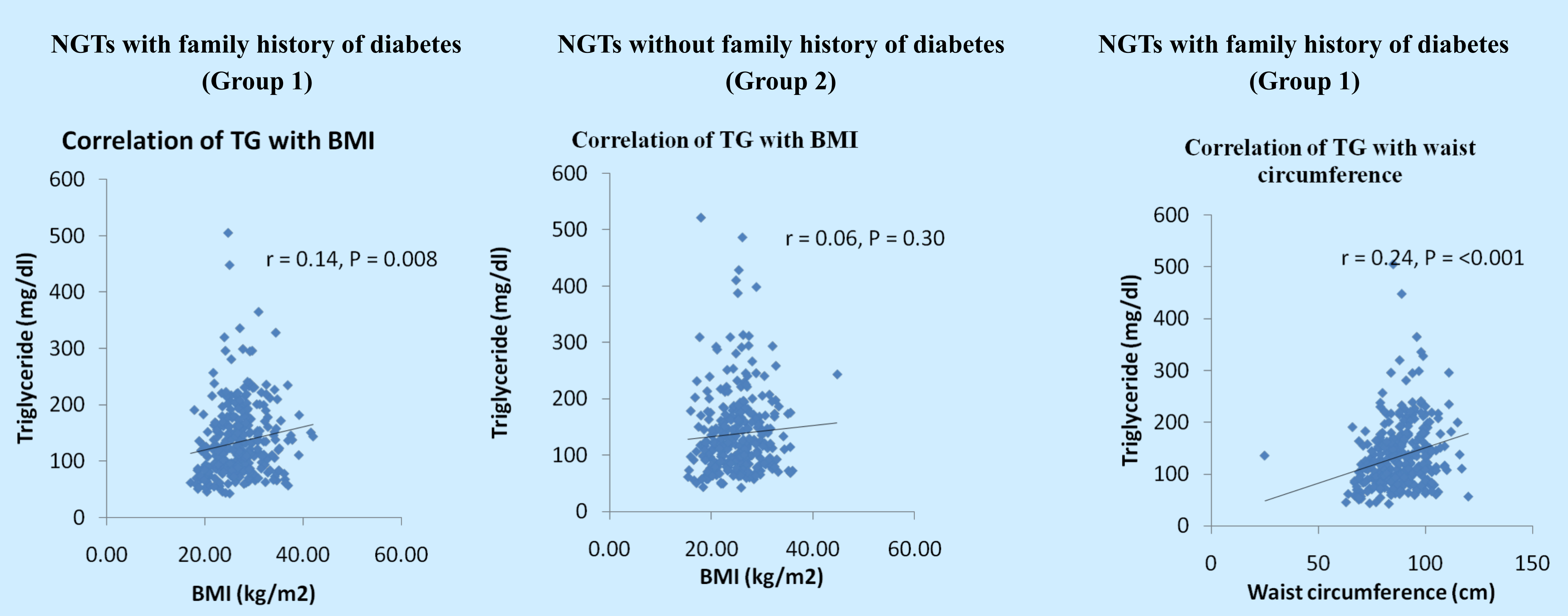

NGTs without family history of diabetes (Group 2)
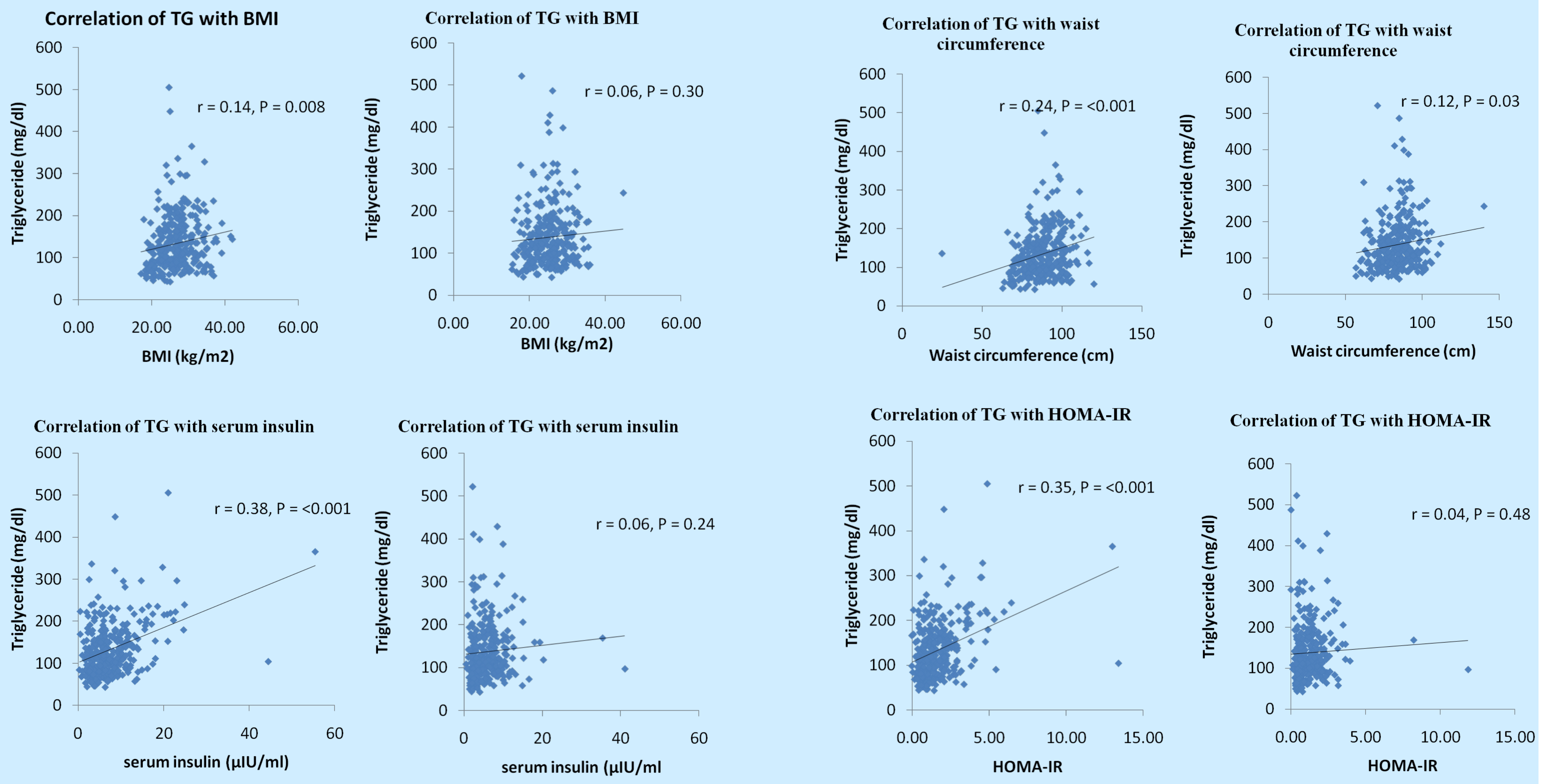

$>$ No other lipid parameter showed any significant correlation with any of the above measures.

\section{SUMMARY OF RESULTS}

$>$ Significantly higher obesity and central obesity in NGTs with family history of diabetes compared to those who had no family history of diabetes.

> Significantly higher glycemic indices in NGTs with family history of diabetes compared to those who had no family history of diabetes.

$>$ Significantly higher serum insulin levels and HOMA-IR in NGTs with family history of diabetes compared to those who had no family history of diabetes.

> Significant positive correlations of triglyceride with serum insulin and HOMA-IR, obesity and waist circumference in NGTs with family history of diabetes.

$>$ No significant correlation of triglyceride with any of the above indices except a weak positive correlation with waist circumference. 